\title{
The Men (and Boys) of the of the Canadian Forestry Corps WWI
}

T he Canadian Forestry Corps played a critical supporting role during World War I. The Western Front in France and Belgium required massive amounts of timber to construct trenches, railway beds, underground bunkers, aircraft hangers, troop shelters, and corduroy roads. In the early years of the war, most of the timber came from North America, but as the war progressed, it became apparent that space on the ships was needed for troops, ammunition, and food. Timber supplies would therefore have to come from forests in the United Kingdom and France. However, local skilled woodsmen were in short supply and in February 1916, Britain asked Canada to raise a special forestry battalion. The $224^{\text {th }}$ forestry battalion was born and consisted of some 1600 recruits, many from the Ottawa Valley, northern Ontario, and Quebec. By May 1916 the battalion was in Europe and hard at work producing the muchneeded timber. As demand grew, the $224^{\text {th }}$ was expanded to six battalions with 101 Companies and became the Canadian Forestry Corps. With woodsmen (called foresters) and support personnel, the CFC had some 33000 men, serving in Scotland, England and France.

Companies working in France were subjected to numerous air raids, and during the German breakthrough of 1918 , they were issued rifles in case the Germans should reach their operations. However, this did not mean that Companies hard at work in Scotland and England had it easy. The hazards of forest operations and the usual sicknesses, including the Spanish flu, took their toll.

The above is based on Al Stinson's Of Relevance article in the July/August 2010 issue, Canadian Forestry Skills to the Rescue -The Canadian Forestry Corps in World War I.

The following is an interesting contribution to Al's article, and comes as a special appeal from John Scott, MBE and member of the Engelfield Green Memorial Committee.

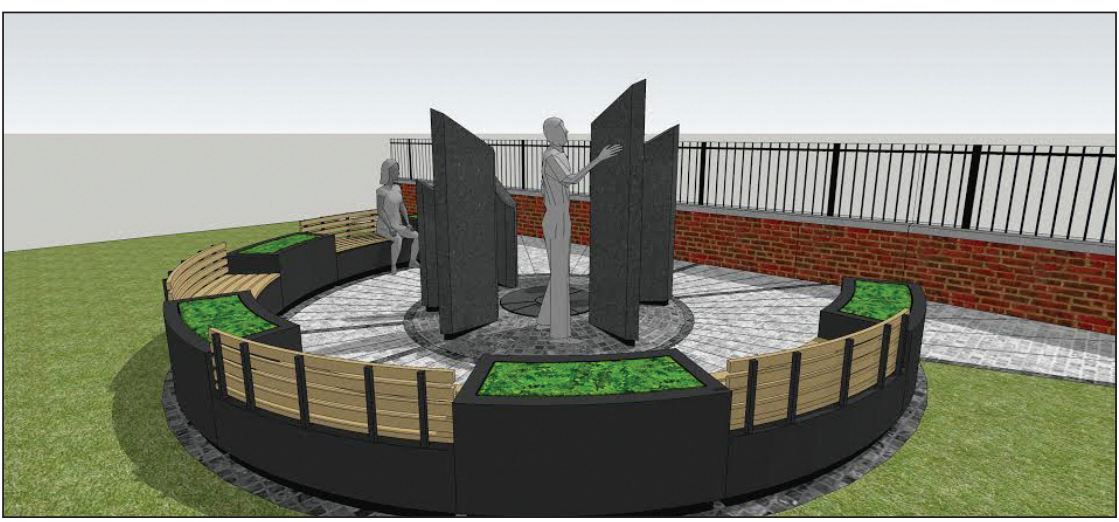

The proposed memorial "Village Sons Remembered"

Englefield Green is a large village in northern Surrey located at the southeastern corner of Windsor Great Park and borders the town of Egham, just west of Heathrow Airport. The CFC had a hospital in WWI in the nearby hamlet of Beech Hill. They made their headquarters at Smith's Lawn, and in 1916 started felling trees at the Virginia Water, Clockcase Plantation. Many of the CFC soldiers served for a time in France, returning to continue their service in Windsor Great Park.

The cemetery at Englefield Green is an old one and contains 91 Commonwealth War Graves, including 30 men of the Canadian Forestry Corps and two of the Canadian Infantry (table 1). There is no tangible record for these men anywhere in the community, and a number of people (The Englefield Green Memorial Committee) are working to create a memorial (Fig. 1) to honour them as well as 59 British servicemen, 94 Englefield Green residents who died in the $1^{\text {st }}$ World War and 23 more who died in WW II. Everyone named on the memorial will be covered under the slogan "Village Sons Remembered". To date, the committee has raised some $£ 38000$ out of a target of $£ 60000$. It will be situated in the grounds of St. Jude's Church and will include the names of all the Canadians buried in the cemetery. The peo- ple behind this initiative hope to achieve their goal by Remembrance Day, November $11^{\text {th }} 2015$.

Statements were made at various times in the Press and by public figures. On July $10^{\text {th }} 1916$ The Times of London noted the valuable contributions of the Canadian lumbermen.

"If you would know the lumberman of Canada and how he works, go to the edge of Windsor Great Park where the crossroad from Virginia Water Station

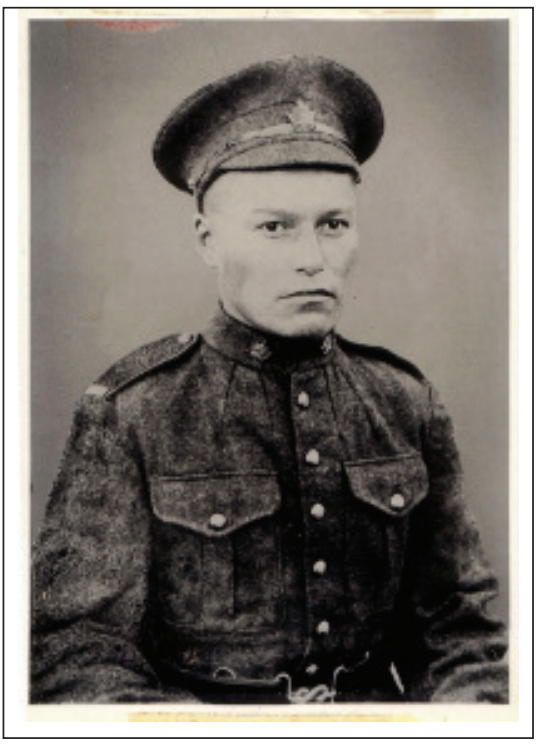

Private John Chookomolin, died $20^{\text {th }}$ September 1917, age 22 


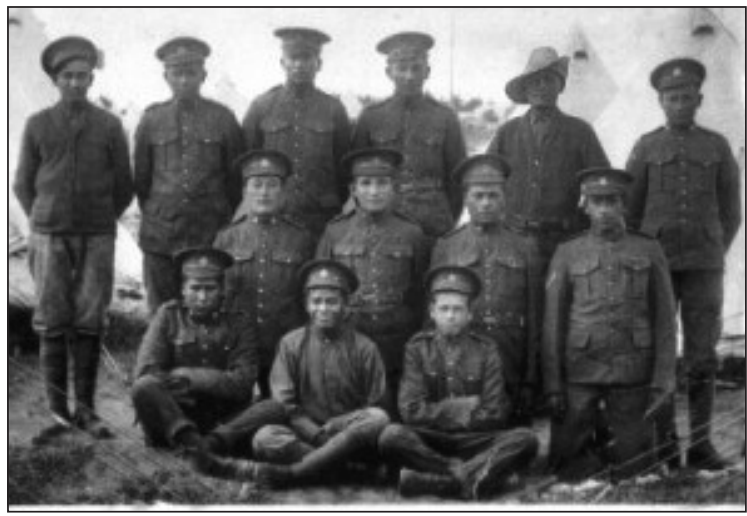

The Boys of Summer 1917.

strikes the main road between Egham and Sunningdale. There, on the Clock Case Plantation, you will see over 150 men of the $224^{\text {th }}$ Canadian Forestry Battalion converting trees into railway sleepers and boards at the rate of anything from 15000 to 20000 board feet a day...The lumber camp is all Canadian - men, machinery and methods. The men, who are drawn from all parts of the Dominion, have the bronzed, healthy look and the easy confident swing which we have learned to look for in Canadians. The khaki under their blue overalls proclaims them soldiers; they draw military pay and they know the rudiments of military drill; but first and last they are woodsmen with their craft at their fingertips."

The valuable contribution of the Canadian Forestry Corps was also remarked upon at the highest levels of the British government. In April 1918, the Earl of Derby, the Secretary of State for War, wrote, "When the Corps understood that it was an order of urgency, and that the material was required for the Front, many of the Companies voluntarily worked long hours without extra pay, some of them doing as much as 90 hours per week...I hope that the Canadian Forestry Corps will realize the real gratitude which we feel for their admirable work, and for the spirit which they have shown throughout in sparing no exertions whenever an opportunity has been afforded them of assisting the fighting men at the Front."

Each of the 30 men of the Canadian Forestry Corps would have a personal story to tell, where they came from, who they left behind, how they got to where they were. After completing basic training in Canada, some embarked for England but then succumbed within days or weeks to one of the various fatal diseases that today are curable. Here is the sad story of Private John Jakomolin - serial no: 2497978. His file tells us that he was a member of the Cree Nation and "enlisted into the Canadian Forestry Corps as part of the Indian Draft in July 1917."

Private John Jakomolin died September $20^{\text {th }}$ 1917. John was a Cree Indian, a First Nation Canadian who came from Attawapiskat in the western James Bay region of north eastern Ontario (Fig. 2). He embarked from Halifax on $5^{\text {th }}$ September 1917 and arrived at Liverpool on the $15^{\text {th }}$. His unit was encamped at the Regimental base on Smith's Lawn in Windsor Great Park near Englefield Green, Surrey. He died of pneumonia just five days later, presumably after a miserable Atlantic crossing. Private John Jakomolin died at Windlesham Military Court Hospital and is buried at Englefield Green, Surrey. The name on his headstone should read "Chookomolin", his rightful family name. It took John's family some 90+ years to locate his grave, as he had been given a different name when he was drafted into the Canadian Forestry Corps. John and the other recruits from Attawapiskat only spoke Cree, and they would not have known that a misinterpretation of his name had taken place. John was one of twenty-four First Nations members from one village (Attawapiskat) to be drafted in June 1917.

"In the summer of 1917, life changed forever for 24 young Cree men from along the James Bay coast near Attawapiskat (Fig. 3). As was our tradition during the summer my people

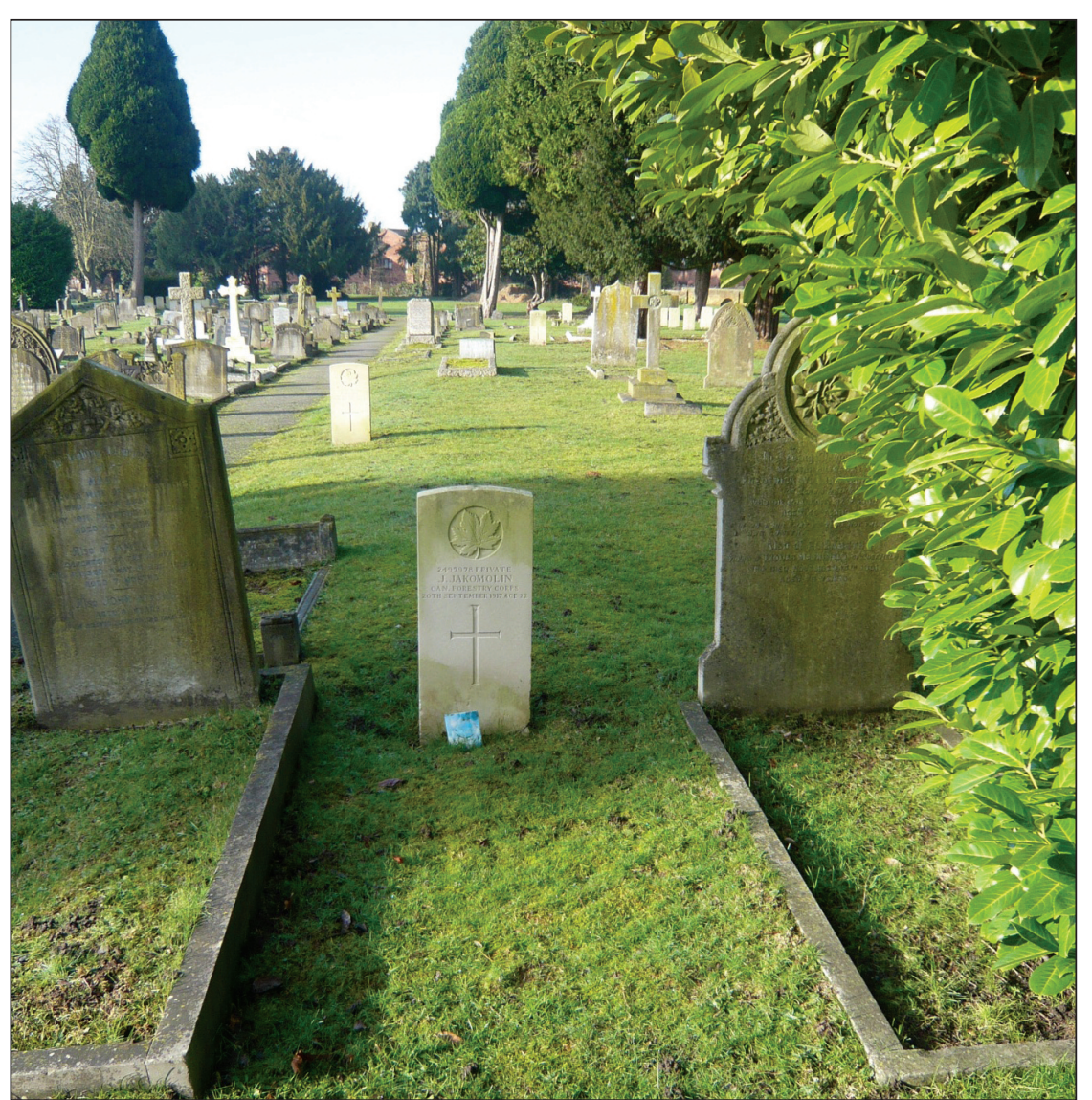

Private John Chookomolin's grave, with his name still spelt incorrectly on his headstone. 
would gather at a place on the James Bay coast on the banks of the Attawapiskat River where Attawapiskat sits today. The story, as handed down by my grandmother Louise Paulmartin, her daughter Susan Kataquapit, who is my mom and by my dad Marius Kataquapit, starts with the appearance of an army recruitment officer.

They tell me that this representative of the government came to the summer gathering place and signed up 24 of our young men, ranging in age from their late teens to mid-twenties. Apparently no one understood what these men had agreed to or where they would be going. It was believed by most that they were heading south for a while to help the government out in some way. It was later discovered that a limit of five young men were to be recruited for the First World War from each settlement along the James Bay coast but for some reason 24 were pulled out of the Attawapiskat area. I am also told that the local priest in the area was not present when the recruiter came to take the young men away and when he returned he was very upset at what had transpired. Imagine the impact on families and the community of Attawapiskat as 24 of the most healthy, strong and vibrant young men were uprooted and taken away.

Of all the men who left that sad summer of 1917, some did not make it back and those who did were changed forever. John Chookmolin, my great grandfather on my mom's side, was never heard from again. There was no telegram, no letter, nothing; he just never came home."

Xavier Kataquapit, grandson of Private John Chookomolin

If you would like to support the efforts of the Englefield Green Memorial Committee to honour the men of the Canadian Forestry Corps, please go to www.villagesonsremembered.org or by E transfer: "The EGVRA Memorial Fund" at Santander, UK; sort code: 0901-28, account \# 67532589. Some might say remembering Private Chookomolin alone would be reason enough to contribute.

\section{Ron Ayling \\ Editor, The Forestry Chronicle}

Trent University in Peterborough, Ontario has recently announced the initiation of a BSc. degree in Water Sciences, the first of its kind in Canada. The program will provide students with the knowledge and skills needed to respond to contemporary water challenges, both in Canada and internationally. Students in this interdisciplinary program will complete courses drawn from the departments of Biology, Chemistry, Environmental and Resource Science/Studies and Geography. These courses will provide the technical and theoretical foundation for the study of the science of water and the aquatic environment. Traditional and interactive lectures and workshops will be complemented by hands-on and experiential learning in the field and in state-of-the-art Trent University laboratories, including Trent's Water Quality Centre, one of the world's premier facilities for environmental contamination research. For further information regarding the Water Sciences degree, please contact Jim Buttle, Department of Geography, Trent University (jbuttle@trentu.ca).

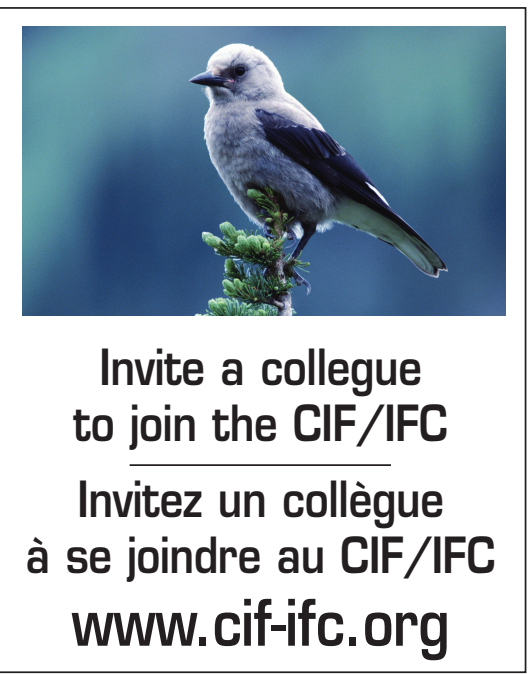

\section{Pôle d'excellence pour la construction écoresponsable en bois}

\begin{abstract}
'Université Laval inaugure la Chaire - industrielle de recherche du CRSNG sur la construction écoresponsable en bois (CIRCERB), une plate-forme unique de recherche consacrée à la réduction de l'empreinte écologique des bâtiments. Ressource renouvelable et abondante au Canada, le bois est au cœur des activités de recherche appliquée de cette chaire jumelée à un consortium d'industriels. En misant sur la conception intégrée et l'analyse de
\end{abstract}

cycle de vie des bâtiments, la chaire de recherche formera des spécialistes de premier plan de la construction écoresponsable en bois.

« Nos travaux visent à réduire l'empreinte environnementale des bâtiments par l'utilisation du bois en tenant compte autant de la conception des bâtiments que de l'utilisateur ", a souligné le titulaire de la chaire et professeur à la Faculté de foresterie, de géographie et de géomatique de l'Université Laval,
Pierre Blanchet.

Les approches étudiées par la chaire généreront des mises en chantier écoresponsables réduisant les émissions de carbone associées aux changements climatiques. En collaboration avec l'industrie, la chaire facilitera également la formation de professionnels spécialisés dans la filière de la construction du bois et des produits forestiers.

" Cette chaire industrielle de recherche repose sur la créativité de nos 